\title{
Differential axonal transport of individual Na,K-ATPase catalytic $(\alpha)$ subunit isoforms in rat sciatic nerve
}

\author{
Marina Mata, Subhash Datta, Chuan-Fang Jin and David J. Fink \\ Department of Neurology, University of Michigan, and GRECC, VAMC, Ann Arbor, MI (USA)
}

(Accepted 6 April 1993)

Key words: Adenosine triphosphatase; Sodium-potassium; Axonal transport; Axon; Neuron; Schwann cell; Western blot

\begin{abstract}
Three isoforms of the Na,K-ATPase catalytic $(\alpha)$ subunit are present in neurons, demonstrated by in situ hybridization of neurons and Western blot of nerve. We used Western blot with antibodies specific for $\alpha 1, \alpha 2$ and $\alpha 3$ peptides to measure the accumulation of individual peptides at a ligature on the sciatic nerve. $\alpha 1$ peptide accumulated with kinetics suggesting rapid axonal transport of that isoform within nerve. $\alpha 2$ and $\alpha 3$ peptides did not accumulate at the ligature. These studies provide insight into the dynamics of axonal Na,K-ATPase isoforms.
\end{abstract}

$\mathrm{Na}, \mathrm{K}-\mathrm{ATPa} e$ is the membrane enzyme found in all eukaryotic cells which exchanges $2 \mathrm{Na}^{+}$for $3 \mathrm{~K}^{+}$, and in the nervous system is responsible for maintaining the transmembrane gradient of $\mathrm{Na}^{+}$and $\mathrm{K}^{+}$, the membrane electrical potential, and cell volume ${ }^{1}$. The functional enzyme is a heterodimer of catalytic $(\alpha)$ and glycosylated $(\beta)$ subunits, although all enzyme and pumping activities are found in the $\alpha$ subunit. Three isoforms of the $\alpha$ subunit have been identified in the nervous system ${ }^{12,13}$. These isoforms are the products of 3 different members of a multigene family ${ }^{11}$. Although a variety of pharmacologic differences between isoforms have been identified in vitro, the specific function of the different isoforms in the nervous system has not been defined.

In situ hybridization studies with riboprobes specific for $\alpha 1, \alpha 2$ and $\alpha 3$ isoforms have demonstrated the presence of mRNAs for each of those isoforms in neurons ${ }^{3,5,10,14}$. It appears that all neurons contain $\alpha 2$ and $\alpha 3$ isoform mRNA, while some neurons also contain $\alpha 1$ mRNA. Glia contain only $\alpha 1$ and $\alpha 2$ isoform mRNAs ${ }^{8}$. Electron microscopic immunocytochemical studies have demonstrated the presence of $\mathrm{Na}, \mathrm{K}$ ATPase both at the node of Ranvier ${ }^{2}$, and in the internodal axolemma of large myelinated fibers ${ }^{7}$, though the ultrastructural distribution of individual isoforms along the axolemma of large myelinated fibers has not been unambiguously defined.

Because protein synthesis in neurons is restricted to the cell body, all axonal proteins are delivered from the cell body into the axon by axonal transport. Membrane proteins and those proteins located within membrane bound organelles are carried at approximately 400 $\mathrm{mm} /$ day from the cell body towards the axon terminal ${ }^{4}$. The transport of specific peptides can be identified by the accumulation of those peptides at a ligature tied around the nerve. Na,K-ATPase is carried by rapid axonal transport in sciatic nerve, as demonstrated by the accumulation of ouabain binding sites at a ligature placed on the nerve ${ }^{6}$, but that study predated the identification of catalytic subunit isoforms.

In order to better define the dynamics of isoform distribution within the axon, we exploited the phenomenon of axonal transport to study the movement of individual isoforms within the axon.

Male Sprague-Dawley rats $(250-300 \mathrm{~g})$ were anesthetized with chloral hydrate and the sciatic nerve exposed in the gluteal region. Two ligatures of 4-0 prolene were tied approximately $1 \mathrm{~cm}$ apart along the nerve in the exposed region. $24 \mathrm{~h}$ later the animals 
were sacrificed by decapitation, the nerve removed, and cut into $3 \mathrm{~mm}$ segments. Four segments proximal to the first ligature, 3 segments distal to the second ligature, and one $3 \mathrm{~mm}$ segment between the ligatures were collected. The tissue was homogenized in $75-100$ $\mu \mathrm{l}$ of $5 \mathrm{mM} \mathrm{NaCl}, 50 \mathrm{mM}$ Tris (pH 7.0), and debris removed by centrifugation at $10,000 \mathrm{rpm}$ for $15 \mathrm{~min}$. A membrane fraction was prepared from the supernatant by centrifugation at $100,000 \times g$ for $1 \mathrm{~h}$. We have previously shown that all of the immunoreactive $\mathrm{Na}, \mathrm{K}$ ATPase in sciatic nerve is found in this fraction ${ }^{7}$.

The amount of $\alpha$ isoform-specific peptide in each segment was determined using Western blot. $15 \mu \mathrm{g}$ of membrane fraction protein was separated by $6 \%$ SDSPAGE and transferred to a nitocellulose membrane (Hybond-ECL, Amersham). The membranes were blocked with $5 \%$ dried milk in Tris buffered saline Tween (TBS-T) and incubated overnight with polyclonal antibodies $(1: 1000)$ directed specifically against $\alpha 1, \alpha 2$ or $\alpha 3$ peptides (Upstate Biotechnologies). The specificities of the antibodies, which were raised against synthetic peptides, has been previously reported ${ }^{12}$. Each experiment was performed with 3 different animals for each isoform (because the majority of the membrane protein from an individual segment was applied to the gel for the Western blot), and was repeated twice. The results of all experiments were identical, and representative blots from control and ligated nerves are shown.

$24 \mathrm{~h}$ after the ligature had been applied, an accumulation of immunoreactive $\alpha 1$ peptide in the segment immediately proximal to the ligature was found (Fig. 1 ), consistent with the rapid axonal transport of that catalytic subunit isoform. There is no accumulation of the $\alpha 1$ peptide distal to the second ligature, suggesting that there is no significant retrograde axonal transport of that isoform. $\alpha 1$ subunit mRNA is found in motor neurons of spinal cord and in DRG neurons, as well as in Schwann cells of sciatic nerve. The results imply that the major portion of $\alpha 1$ peptide in the nerve is axonal, since glial $\mathrm{Na}, \mathrm{K}$-ATPase would not be transported, and would not accumulate at the ligature.

$\alpha 2$ isoform is found in both glia and in neurons ${ }^{8} .24$ $\mathrm{h}$ after ligature the amount of $\alpha 2$ peptide was essentially similar in all nerve segments (Fig. 1). Because these antibodies do not function in electron microscopic immunoctyochemistry, it was not possible for us to determine whether this distribution represents the stability of subunit isoforms present in Schwann cells, or the relative stability and immobility of axolemmal $\alpha 2$ subunits.

A similar picture was seen with the $\alpha 3$ isoform, which showed no evidence of accumulation at the ligature (Fig. 1). Unlike the $\alpha 2$ isoform, $\alpha 3$ mRNA is found exclusively in neurons, and is not found in the Schwann cells of the sciatic nerve ${ }^{10} . \alpha 3$ must therefore be transported from the neuronal cell body to the axonal membrane, but the small incremental amount added over the $24 \mathrm{~h}$ that the ligature is present is not detected, so that an apparent rate of transport cannot be determined. $\alpha 3$ peptide immunoreactivity in individual segments must represent axonal $\alpha 3$ which is relatively stable in the membrane.

Although we do not have immunocytochemistry with these antibodies, the accumulation proximal to the

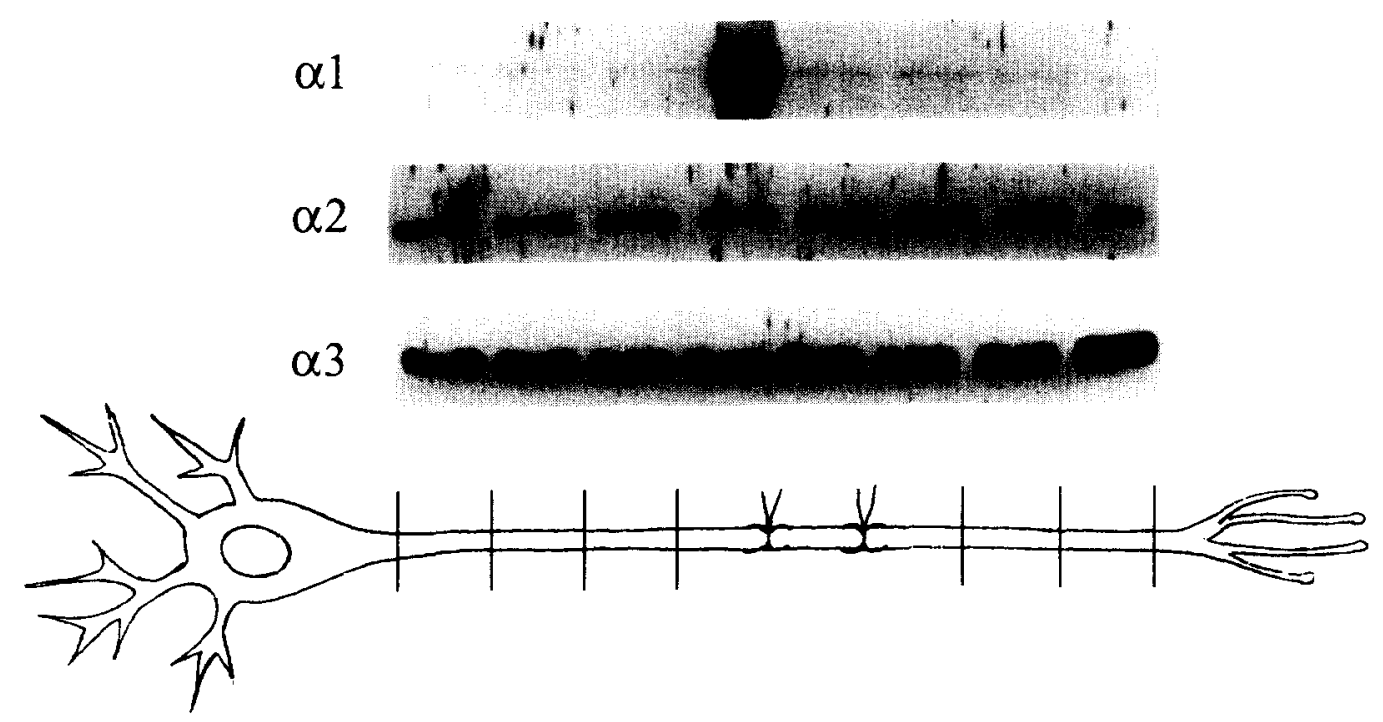

Fig. 1. Western blot of individual Na,K-ATPase $\alpha$ isoforms in sequential $3 \mathrm{~mm}$ segments of sciatic nerve, $24 \mathrm{~h}$ after application of a ligature about the nerve, as indicated in the diagram. The cell body is indicated schematically, and segments proximal to the ligature are to the left, those distal to the ligature to the right. $15 \mu \mathrm{g}$ of membrane fraction protein was run in each lane. 
ligature of $\alpha 1$ does not represent an artifact of inflammatory cells. If that were the case, we would expect to see an accumulation about the second ligature as well, and there is no such accumulation of $\alpha 1$ peptide.

In the control nerve, the amount of peptide in individual segments is relatively constant across the length of the nerve (Fig. 2). Although the amount of $\alpha 1$ peptide in the segments of the ligated nerve, excluding the segment just proximal to the ligature, appears to be less than the level in the contralateral nerve, this was not the case. When segments from the ligature and control nerve were run together on a single gel, no differences between the sides was apparent (data not shown). In addition, dot blot analysis of $\alpha 1$ isoform mRNA levels in the dorsal root ganglia of ligature compared to control nerve showed no difference between the two sides (data not shown).

The results of this study have important implications for our understanding of the dynamics of Na,K-ATPase isoform distribution within neurons. $\alpha 1$ and $\alpha 3$ are both found predominantly in neurons, but while virtually all $\alpha 1$ appears to be carried by rapid axonal transport, $\alpha 3$ is predominantly non-mobile over a $24 \mathrm{~h}$ period. The induction of $\alpha 1$ mRNA by electrical activity in hypothalamic neurons ${ }^{9}$ has led us to propose that $\alpha 1$ isoform functions to pump $\mathrm{Na}^{+}$which enters with electrical depolarization. We would propose that $\alpha 1$ is found predominantly at the nerve terminals and at particular nodes of Ranvier, and for that reason is rapidly transported. $\alpha 3$, which is relatively stable in the membrane, may represent an axolemmal form, present along both the internodal axolemma and the axolemma of unmyelinated fibers principally in a non-mobile form.
Because $\alpha 2$ is found in glia as well, it is not possible to determine whether its stability represents the predominant glial location, or immobility of the axonal fraction of that isoform.

Further definition of the distribution of these isoforms awaits the development of antibodies that can be used for electron microscopic immunocytochemical studies.

This work was supported by grants from the VA (M.M. and D.J.F.) and by NIH Grant NS 27771 (D.J.F.). We acknowledge the excellent technical assistance of Mr. Daniel Cutler in illustration.

1 Albers, R.W., Siegel, G.J. and Stahl, W.C., Membrane transport. In G.J. Siegel, B.W. Agranoff, R.W. Albers and P.B. Molinoff (Eds.), Basic Neurochemistry, Little/Brown, Boston, 1989, pp. 49-70.

2 Ariyasu, R.G., Nichol, J.A. and Ellisman, M.H., Localization of sodium/potassium adenosine triphophatase in multiple cell types of the murine nervous system with antibodies raised against the enzyme from kidney, J. Neurosci., 5 (1985) 2581-2596.

3 Filuk, P.E., Miller, M.A., Dorsa, D.M. and Stahl, W.L., Localization of messenger RNA encoding isoforms of the catalytic subunit of $\mathrm{Na}, \mathrm{K}-\mathrm{ATPase}$ in rat brain by in situ hybridization histochemistry, Neurosci. Res. Commun., 5 (1989) 155-162.

4 Grafstein, B. and Forman, D.S., Intracellular transport in neurons, Physiol. Rev., 60 (1980) 1167-1283.

5 Hieber, V., Siegel, G.J., Fink, D.J., Beaty, M.W. and Mata, M., Differential distribution of $\mathrm{Na}, \mathrm{K}$-ATPase alpha isoforms in the central nervous system, Cell Mol. Neurobiol., 11 (1991) 253-262.

6 Lombet, A., Laduron, P., Mourre, C., Hacomet, Y. and Laxdunski, M., Axonal transport of $\mathrm{Na}^{+}, \mathrm{K}^{+}$-ATPase indentified as a ouabain binding site in rat sciatic nerve, Neurosci. Lett., 64 (1986) 177-183.

7 Mata, M., Fink, D.J., Ernst, S.A. and Siegel, G.J., Immunocytochemical demonstration of $\mathrm{Na}, \mathrm{K}$-ATPase in internodal axolemma of myelinated fibers, J. Neurochem., 57 (1991) 184-192.

8 Mata, M., Fink, D.J., Hieber, V. and Knapp, P.E., Isoform-specific expression of Na,K-ATPase in glial cells, J. Cell Biol., 115 (1991) 310a (Abstr.).

9 Mata, M., Hieber, V., Beaty, M., Clevenger, M. and Fink, D.J.,
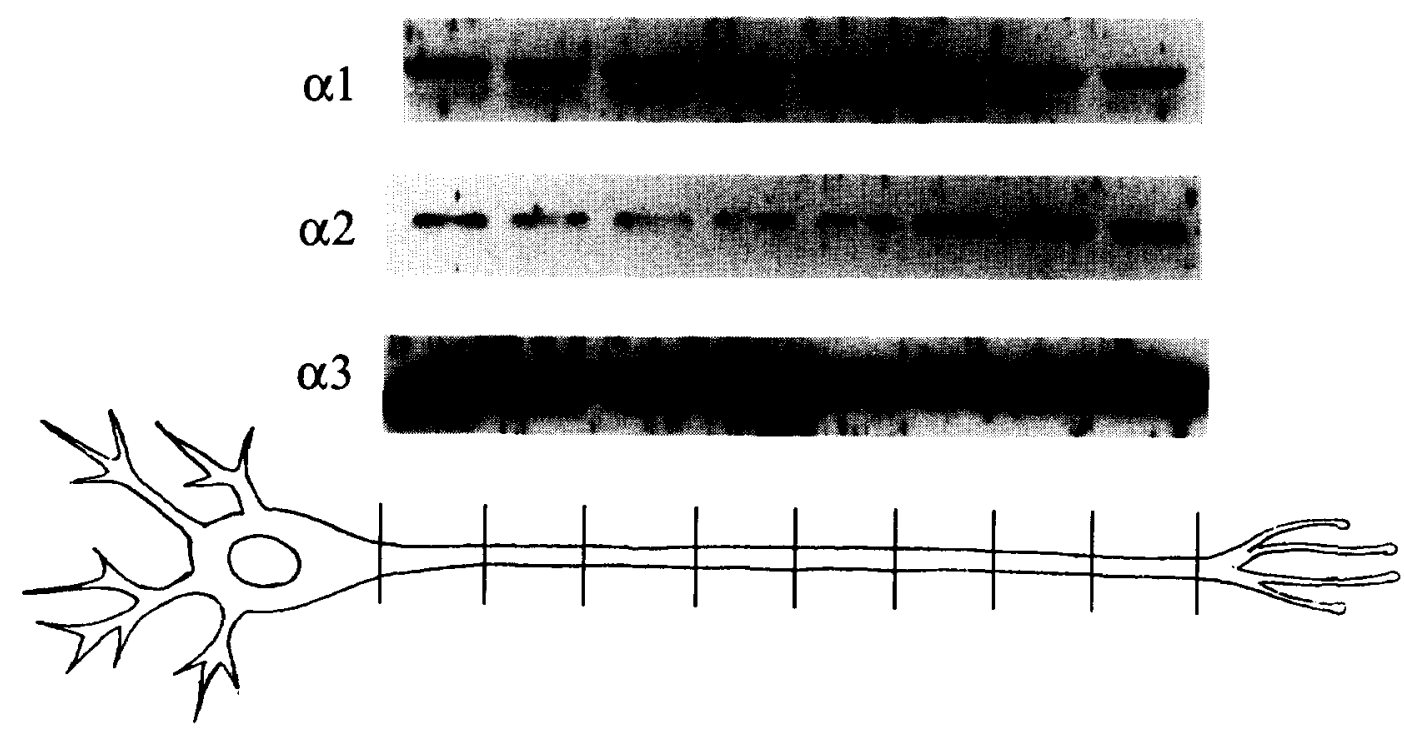

Fig. 2. Western blot of individual Na,K-ATPase $\alpha$ isoforms in sequential $3 \mathrm{~mm}$ segments of control (contralateral) sciatic nerve, processed in parallel with those samples shown in Fig. 1. 
Activity-dependent regulation of Na,K-ATPase alpha isoform mRNA expression in vivo, J. Neurochem., 59 (1992) 622-626.

10 Mata, M., Siegel, G.J., Hieber, V., Beaty, M.W. and Fink, D.J., Differential distribution of Na,K-ATPase alpha isoforms in the peripheral nervous system, Brain Res., 546 (1991) 47-54.

11 Shull, G.E., Greeb, J. and Lingrel, J.B., Molecular cloning of three distinct forms of the $\mathrm{Na}^{+}, \mathrm{K}^{+}$-ATPase alpha-subunit from rat brain, Biochemistry, 25 (1986) 8125-8132.

12 Shyjan, A.W. and Levenson, R., Antisera specific for the alpha-1, alpha-2, alpha-3, and beta subunits of the Na,K-ATPase: differ- ential expression of alpha and beta subunits in rat tissue membranes, Biochemistry, 28 (1989) 4531-4535.

13 Urayama, O., Shutt, H. and Sweadner, K.J., Identification of three isozyme proteins of the catalytic subunit of the $\mathrm{Na}, \mathrm{K}$ ATPase in rat brain, J. Biol. Chem., 264 (1989) 8271-8280.

14 Watts, A.G., Sanchez-Watts, G., Emanuel, J.R. and Levenson, R., Cell-specific expression of mRNAs encoding Na,K-ATPase alpha- and beta-subunit isoforms within the rat central nervous system, Proc. Natl. Acad. Sci. USA, 88 (1991) 7425-7429. 